\title{
The Influence of Head of Study Programs Competence towards Organizational Commitments
}

\author{
H. Salahuddin ${ }^{1}$, Mukhtar $^{1}$, Risnita ${ }^{1}$, Muhamad Taridi ${ }^{2 *}$ \\ ${ }^{1}$ School of Postgraduate UIN, Sulthan Thaha Saifuddin, Jambi \\ ${ }^{2}$ UIN Sulthan Thaha Saifuddin, Jambi
}

DOI: $10.36348 / \mathrm{sb} .2019 . \mathrm{v} 05 \mathrm{i} 12.018$

| Received: 05.12.2019 | Accepted: 12.12.2019 | Published: 30.12.2019

*Corresponding author: Muhamad Taridi

\section{Abstract}

The purpose of this study was to test the hypotheses of the influence of the head of the Study Program Competence, and Organizational Commitment in Islamic Higher Education in Jambi Province. This research is quantitative research with a survey method. The sampling technique used probability sampling with a sample size of 60 respondences. Path analysis was applied for hypothesis testing with a significance level $a=0.05$. The results of this study revealed that both partially and simultaneously there were influences: 1). There is a direct influence on the competency of the Head of the study Program (X1) on organizational commitment (X2). Based on the results of the analysis calculation, the value of $t$ obtained (9.14) > t table (1.987), so that $\mathrm{H} 0$ is rejected and H1 is accepted. It means that the competency of the head of the study program that developed in the institution had a significant influence on organizational commitment. This study implied that the results obtained from this study provide information that Organizational Commitment can be improved by providing an increase in each variable supporting the organizational commitment under study, it could not be done simply by ignoring the other variables in the path of the variable under study.

Keywords: Competency of head of study programs, work motivation, organizational commitment.

Copyright @ 2019: This is an open-access article distributed under the terms of the Creative Commons Attribution license which permits unrestricted use, distribution, and reproduction in any medium for non-commercial use (NonCommercial, or CC-BY-NC) provided the original author and source are credited.

\section{INTRODUCTION}

Managing human resources in an organization is not easy because it involves various elements in the organization, namely lecturers, employees, and leaders and the management system of the college itself. The combination of the two elements becomes the duty of a leader to be managed to create a conducive work environment. A conducive environment is expected to create job satisfaction. Management of higher education is strived to change the conservative mind-set that seems slow to change a more effective and efficient education system.

The role of human resources in an organization is a very important determinant of the effectiveness and success of the organization in achieving its goals. The success and performance of a person in a field of work are largely determined by the level of competence, professionalism, and also his commitment to the field occupied by him. As something that is positively related to performance, a commitment that is an attitude and behaviour that can be seen as driving people to work is closely interrelated. The existence of a commitment can be an encouragement for someone to work better or even otherwise cause someone to just leave his job, due to a demand for other commitments. An organizational commitment shows a person's power in identifying his involvement in a part of the organization. Organizational commitment is built on the belief of workers on organizational values, the willingness of workers to help realize the goals of the organization and loyalty to remain a member of the organization. Therefore organizational commitment will cause a sense of belonging (sense of belonging) for workers to the organization. If the worker feels that he is bound by existing organizational values, he will feel happy at work, so that his performance can improve. In an organization there is also a belief that organizational commitment can increase job satisfaction. Besides organizational commitment, to achieve organizational goals in a better direction requires motivation both internally and externally. Internal motivation is motivation that arises from the mind, heart, and desires. External motivation is motivation that arises because of 
impulses from outside the personal, for example from other people and organizations where they work.

Besides competence to influence organizational commitment, it also depends on work motivation. High organizational commitment can lead to motivation for someone to do something with full sincerity. This is based on the assumption that working without motivation will quickly get bored, because there is no motivating element so that morale remains stable. According to Hasibuan, motivation is very important because motivation is the thing that causes, distributes and supports human behaviour, so that they want to work hard and enthusiastically achieve optimal results [1]. Motivation is a commodity that is needed by everyone including lecturers. Motivation is needed to run a life, lead a group of people and achieve organizational goals. Work motivation is a drive that grows and develops from within the lecturer to do the best possible work so that the goals will be achieved. Work motivation can occur if the lecturer has pride in success. The task of teaching for the sake of building quality human resources in order to make quality education a proud and challenging task, so that lecturers should have high work motivation.

\section{LITERATURE REVIEW \\ Organizational Commitment}

This study refers to the integrative model of organization Behaviour in Organizational Behaviour Improving Performance and Commitment in the Workplace by Colquitt, Lepine and Wesson, in the model there are endogenous variables namely Job Performance and Organizational Commitment (organizational commitment), while exogenous variables consist of: (1) organizational mechanisms consist of organizational culture and organizational structure, (2) group mechanisms consist of leadership styles and behaviours, leadership power and influence, team processes and team characteristics, (3) individual characteristics consist of personality and cultural values and abilities, (4) individual mechanisms consisting of job satisfaction, stress, motivation, trust, justice \& ethics and learning \& decision making, as a whole are shown in Figure-1 below:

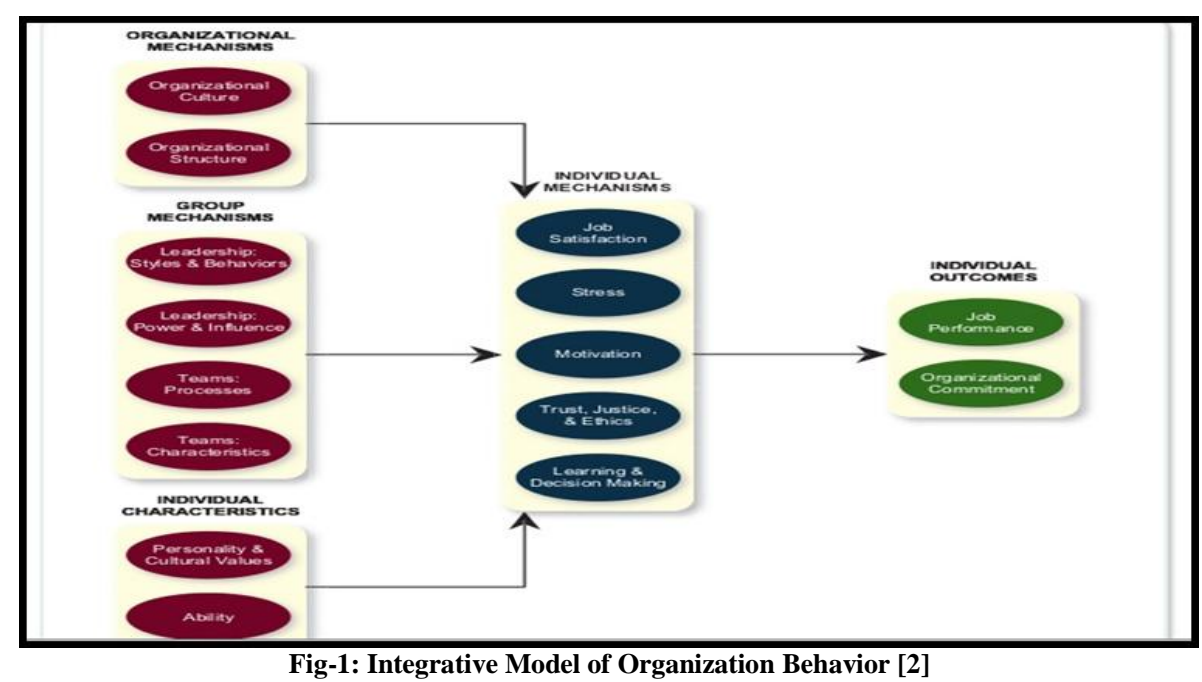

According to Schermerhorn John $\mathrm{R}$ et al., Organizational commitment is the loyalty of an individual to the organization (organizational commitment, or the level of loyalty felt by individuals to the organization). Research on organizational commitment into two main dimensions, namely (1) rational commitment reflects the feeling that the work serves a person's financial, developmental, and professional interests, and (2) emotional commitment reflects the feeling that what a person does is important, valuable, and real useful for others. The results of his research are strong emotional commitment to the organization, based on the values and interests of others, as much as four times stronger in influencing performance positively than rational commitment, based primarily on salary and personal interests [3].

Referring to the point of view above that people who have good organizational commitment will behave 1) Have a sense of pride in the organization; 2) Working for long periods of time at the institution or organization; 3) A person who has high organizational commitment will be firm in his work and have loyalty to the organization.

\section{Competencies of Head of Study Program (X2)}

Competence comes from the word "competency", which means ability or skill. According to the Big Indonesian Dictionary, competence can be interpreted as the authority or power to determine or decide on a matter. According to Charles E. Johnson, in Mulyasa, argued that competence is a rational behaviour to achieve the required goals in accordance with the expected conditions [4].

Competence is an ability (skill \& knowledge) to carry out or carry out activities / jobs / tasks [5]. Commensurate with that opinion Sutrisno also 
mentioned that competence is an ability based on skills and knowledge that is supported by the attitude of performance and its application in carrying out tasks and work in the workplace that refers to the requirements applied. Quoting Gardon's opinion in the book, some aspects contained in competencies are: (1) knowledge (knowledge), namely intelligence in the cognitive field, (2) knowledge (understanding), namely the cognitive depth owned by individuals, (3) ability (skill), namely the ability to carry out the task or work charged to him, (4) value (value), namely the standard of behaviour that has been believed and has been psychologically integrated, (5) attitude (attitude) that is a feeling or reaction to stimuli from outside, and (6) interest ( interest) is the tendency for someone to do something [6]. Competence according to the meaning of competence when referring to the Minister of Education Decree No. 048 / U 2002, expressed as a set of smart actions that are full of responsibility that a person has as a condition to be considered capable by the community in carrying out tasks in certain fields [7].

Spencer and Spencer in Samsir Torang, stated that the competence of each person in the organization consists of three levels, namely: (1) behavioural tools that consist of knowledge (cognitive knowledge /ability) and skills (skills/psychomatoic abilities), (2) image attribute that is consists of social roles (patterns of behaviour in social groups) and self-images (views of himself), (3) personal characteristics of traits (typical of good listening behaviour) and motive (motivated for achievement, analysis and power) [8].

\section{MATERIAL AND METHODS}

This research uses quantitative research methods, which is a study that will reveal, find and explore information about organizational culture, the competence of the head of study programs in generating work motivation for students towards the organizational committee at the Private Islamic High School. This study uses a survey method, with a causality approach. Data will be analyzed using inferential statistics with the Path Analysis Method to find out whether there is a direct or indirect effect of each research variable. The target population in this study is the Chair of the Study Program and Students. Research samples as many as 90 people. The number of samples can be said to have representational value. How to determine respondents is done by selecting a simple random sample. Trial samples for this research instrument test were used by 30 students and 60 research samples. Research instruments using questionnaires and documentation. Data analysis techniques using 1) Descriptive analysis is a form of data analysis to test the generalization of research results based on one sample. Descriptive analysis consists of presenting data in the form of tables and graphs. The data presented is data about the mean, median, mode, and standard deviation. Descriptive analysis is performed to describe each data obtained on each variable. 2) Inferential analysis is a statistic used to analyze sample data, and the results will be generalized (referenced) for the population where the sample was taken [9]. Inferential analysis using statistical formulas (competency test and regression analysis). Before the hypothesis is tested first, the analysis requirements test is done by means of a normality test and a homogeneity test.

\section{RESULTS \\ Research Data Description}

The description of the data presented in this section includes the data, the Competence of the Head of the Study Program on Organizational Commitment, after being processed using descriptive statistics with the SPSS Version 22.0 program, a measure of central tendency is obtained as shown in the following table:

Table-1: SPSS Descriptive Calculation Table 22

\begin{tabular}{|l|l|l|l|}
\hline \multicolumn{2}{|l|}{} & Head of study program competence & Organization commitment \\
\hline \multirow{2}{*}{$\mathrm{N}$} & Valid & 60 & 60 \\
\cline { 2 - 4 } & Missing & 0 & 0 \\
\hline Mean & 152.45 & 144.75 \\
\hline Std. Error of Mean & 1.106 & 1.032 \\
\hline Median & 153 & 145 \\
\hline Mode & 153 & 145 \\
\hline Std. Deviation & 8.49 & 7.96 \\
\hline Variance & 73.404 & 63.953 \\
\hline Range & 41 & 40 \\
\hline Minimum & 132 & 125 \\
\hline Maximum & 173 & 165 \\
\hline Sum & 9147 & 8685 \\
\hline
\end{tabular}

\section{Testing Requirements Analysis Normality Test}

Based on the results of normality test calculations, a normality test result summary can be noted as follows: 
Table-2: Summary of Normality Test Calculation Results

\begin{tabular}{|l|l|l|l|l|l|}
\hline No & Variabel & $\mathbf{N}$ & $\chi^{2}$ obtained & $\chi^{2}$ table & $\begin{array}{l}\text { Remarked } \\
\chi^{2} \text { obtained }\end{array} \chi^{2}$ table \\
\hline 1 & Head of study program competence & 60 & 0,39 & 11,070 & Normal \\
\hline 2 & Organization commitment & 60 & 0,84 & 11,070 & Normal \\
\hline
\end{tabular}

\section{Homogeneity Test}

A summary of the homogeneity test results can be noted in the following table:

Table-3: Summary of Homogeneity Test

\begin{tabular}{|l|l|c|c|c|l|}
\hline No & Variable & $\mathbf{d k}$ & $\chi^{2}$ obtained & $\chi^{2}$ table & Remarked \\
\hline 2 & $\mathrm{X}_{1}$ toward $\mathrm{X}_{2}$ & 31 & 15,77 & 44,90 & Homogeneous \\
\hline
\end{tabular}

Test for Linearity and Significance of Regression Coefficients

A summary of the results of the Linearity test can be noted in the following table:

Table-4: Summary of Homogeneity Test

\begin{tabular}{|l|l|l|l|l|l|}
\hline No & Variable & dk & $\mathbf{F}_{\text {obtained }}$ & $\mathbf{F}_{\text {table }}$ & Remarked \\
\hline 2 & $\mathrm{X}_{1}$ toward $\mathrm{X}_{2}$ & 60 & 0,08 & 1,66 & Linear \\
\hline
\end{tabular}

The results of the study found that the total influence of the Competency of the Study Program Chair (X1) on Organizational Commitment (X2) was $31.74 \%$. The level of Organizational Commitment is affected by the Study Program Chair Competency of $31.74 \%$, this information means that the level of Organizational Commitment can be done by improving the Study Program Head Competency level, of the three variables studied the contribution of Study Program Chair Competency variables that has the most influence on Organizational Commitment.

The importance of the competence of the Chair of the Study Program is supported by Hijazeh's opinion in Jeni, saying that there is alignment, a term used to describe how competence is related to the organization's strategic objectives to be achieved and the talents that constitute the individual expertise needed to achieve them [10].

\section{DISCUSSION}

Hypothesis: There is a direct influence on the Competence of the Head of the Study Program on Organizational Commitment.
The hypothesis states that the Head of Study Program Competencies (X1) directly influences Organizational Commitment (X2). Statistical Hypothesis:

$$
\begin{aligned}
& \mathrm{H}_{0}: \mathrm{p}_{42} \geq 0 \\
& \mathrm{H}_{1}: \mathrm{p}_{42}<0
\end{aligned}
$$

Hypothesis testing criteria $\mathrm{HO}$ is rejected if $\mathrm{t}$ obtained $>\mathrm{t}_{\text {table }}$, and $\mathrm{H}_{0}$ is accepted if $\mathrm{t}$ obtained $<\mathrm{t}$ table. Based on the results of data analysis manually obtained path coefficient $X 1$ to $X 2(\rho 42)=0.3102$ with a real level $\alpha=0.05$ and $\mathrm{df}=58$ obtained value of table $=$ 1.987. The calculation results get the $\mathrm{t}$-count $=9.14$.

Based on these criteria it turns out that the value of $\mathrm{t}$ obtained $(9.14)>\mathrm{t}$ table $(1.987)$, so that $\mathrm{H}_{0}$ is rejected and $\mathrm{H}_{1}$ is accepted. This means that the research hypothesis which states that the Competency of the Chairperson of the Study Program (X1) has a direct effect on Organizational Commitment (X2) can be accepted because it has been tested for its truth. Manual calculations get the same number as calculations using SPSS ver.22 can be seen in the following Table-6:

Table-6: Results of Path Analysis between the Competencies of Study Program Chair (X1) and Organizational

\begin{tabular}{|c|c|c|c|c|c|c|}
\hline \multicolumn{7}{|c|}{ Coefficients $^{\text {a }}$} \\
\hline \multirow{2}{*}{\multicolumn{2}{|c|}{ Model }} & \multicolumn{2}{|c|}{$\begin{array}{l}\text { Unstandardized } \\
\text { Coefficients }\end{array}$} & $\begin{array}{l}\text { Standardized } \\
\text { Coefficients }\end{array}$ & \multirow[t]{2}{*}{$\mathrm{t}$} & \multirow[t]{2}{*}{ Sig. } \\
\hline & & $\mathrm{B}$ & Std. Error & Beta & & \\
\hline \multirow[t]{3}{*}{1} & (Constant) & 19,035 & 10,163 & & 1,873 & ,066 \\
\hline & organization commitment &, 552 & ,083 & ,360 & 6,643 &, 000 \\
\hline & $\begin{array}{l}\text { head of study program } \\
\text { competence }\end{array}$ &, 060 &, 125 & ,3102 & ,477 & ,635 \\
\hline
\end{tabular}
Commitment (X2) 
In Table- 6 the results of $\rho 42=0.3102$ [12], both calculation results manually or using the SPSS program, show the same path coefficient value $\rho 42=$ 0.3102 . Meanwhile, to state the size of the contribution (contribution) the Competency of the Study Program Head (X1) to Organizational Commitment (X2) is as follows:

a. The magnitude of the direct effect of exogenous variables (X1) on endogenous variables (X2):

$\rho_{X_{4} X_{2}} \times \rho_{X_{4} X_{2}}=0,3102 \times 0,3102=0,096(9,6 \%)$.

b. The magnitude of the effect of total exogenous variables (X1) on endogenous variables (X2)

$\left[\rho_{X_{4} X_{2}} x \rho_{X_{4} X_{2}}\right]+\left[\rho_{X_{4} X_{2}} x r_{x_{2} x_{3}} x \rho_{X_{4} X_{3}}\right]=0,096+0,057=0,153(15,3 \%)$.

Based on the results of the above calculation, the magnitude of the effect of the Competency of the Head of Study Program (X1) on Organizational Commitment (X2) is $15.3 \%$, while the remaining $84.7 \%$ is influenced by other variables.

The results of the study found that the total influence of the Competency of the Study Program Chair (X1) on Organizational Commitment (X2) was $31.74 \%$. The level of Organizational Commitment is affected by the Study Program Chair Competency of $31.74 \%$, this information means that the level of Organizational Commitment can be done by improving the Study Program Head Competency level, of the three variables studied the contribution of Study Program Chair Competency variables that has the most influence on Organizational Commitment.

The results of this study are supported by the theory that organizational commitment is one of the variables that affects it, namely individual characteristics in which there are abilities, which explains that, human abilities consist of cognitive abilities, emotional abilities, and physical abilities [11].

\section{CONCLUSION}

Based on the analysis of data processing and discussion that has been presented in the previous chapter. So the conclusions drawn in this study are as follows:

1. There is a direct influence on the competence of the Head of the Study program (X1) on job satisfaction (X2). It means that the extent of the competency of the head of the study program has a direct impact on the level of organizational commitment of Islamic religious high schools in Jambi province.

2. The competency of the Head of the Study Program (X1) has a significant positive direct effect on job satisfaction (X2). The better the competency of the head of the study program, the level of Commitment of Islamic Higher Education Organizations in Jambi Province will increase. Improvements in the field of competence will make a significant contribution to the Commitment of Islamic High School Organizations in Jambi province.
3. Positive steps to improve competence is one of the efforts that can be made in achieving high organizational commitment. The requirements mandated by Law number 14 of 2005 concerning teachers and lecturers, four competencies that must be owned by teachers/ lecturers are pedagogical competencies, personality competencies, social competencies, and professional competencies. The level of organizational commitment of an individual is also determined by the culture of the organization.

\section{REFERRENCE}

1. Hasibuan, M. S. P. (2013). Manajemen Sumber Daya Manusia, Jakarta: Bumi Aksara, 141.

2. Colquitt, J. A., LePine, J. A., \& Wesson, M. J. (2017). Organizational Behaviour Improving Performance and Commitment in the Workplace. 4.

3. John, S., \& John, R. (2010). Organizational Behaviour. $11^{\text {th }}$ Editions (America: John Wiley Inc., \& Sons, 72.

4. Mulyasa, E. (2011). Standar Kompetensi dan Sertifikasi Guru, (Bandung: PT Remaja Rosdakarya, 25.

5. Torang, S. (2013). Organisasi \& Majajemen (Prilaku, Struktur, Budaya \& Perubahan Organisasi) (Bandung: Alfabeta, 53.

6. Edy Sutrisno. (2012). Manajemen Sumber Daya Manusia, cetakan ke-4, Jakarta: Prenada Media Group, 208-209.

7. Hawi, A. (2017). Kompetensi Guru Pendidikan Agama Islam, 1

8. Torang, S. (2013). Organisasi \& Majajemen (Prilaku, Struktur, Budaya \& Perubahan Organisasi) (Bandung: Alfabeta. 56.

9. Sugiyono. (2006). Statistika Untuk Penelitian, Bandung: CV ALFABETA, 23.

10. Wulandari, J., Raharja, S. U., Nurasa, H., \& Muhyi, H. (2018). Identifikasi kompetensi manajerial pada level manajemen menengah dalam industri perbankan Indonesia. Jurnal Siasat Bisnis, 22(01), 20-37.

11. Colquitt, J. A., LePine, J. A., \& Wesson, M. J. (2017). Organizational Behaviour Improving Performance and Commitment in the Workplace. 323. 